\section{Crown-Root Fractures in Primary Teeth: A Case Series Study of 28 Cases}

Vanessa Polina Pereira da Costa ${ }^{1}$, Luisa Jardim Correa Oliveira ${ }^{1}$, Denise Paiva Rosa1, Mariana Gonzalez Cademartori1, Dione Dias Torriani2 (in memoriam)
1Post-Graduate Program, Dental School, UFPel - Universidade Federal de Pelotas, Pelotas, RS, Brazil 2Department of Social and Preventive Dentistry, Dental School, UFPel - Universidade Federal de Pelotas, Pelotas, RS, Brazil

Correspondence: Vanessa Polina Pereira da Costa, Rua Gonçalves Chaves, 457, 96015-560 Pelotas, RS, Brasil. Tel: +55-53-3225-6741 e-mail: polinatur@yahoo.com.br

Key Words: child, tooth injuries, tooth fracture, primary teeth, cases study.

\section{Introduction}

Crown-root fractures involve enamel, dentin and cement (1). These are not usually found in primary dentition, and approximately $2 \%$ of all types of traumatic dental injures (TDI) (2). Frequently, this kind of dental trauma spreads to the subgingival or intraosseous level, which complicates the establishment of the extent and direction of fracture lines, even with the assistance of radiographic examination (3). The difficulty of tooth maintenance and periodontal health require an interdisciplinary approach to enable the appropriate treatment of this type of TDI (4).

Crown-root fractures in primary teeth are singular events with wide variations of fracture patterns and that making the correct diagnosis and treatment plan can be complex. In addition, there have been very few reports regarding this type of trauma and studies that describe the best approaches for each situation are necessary to enable dentists to make the best treatment decision. Therefore, the aim of the present study was to present a case series of crown-root fractures in primary teeth of patients who were followed-up until the eruption of permanent successor teeth.

\section{Material and Methods}

The study was approved by the Ethics Committee of the Dental School of the Federal University of Pelotas (\#21/2008). Parents of all children signed an informed consent form. Children received full dental treatment.

This retrospective case series study describes crown-root fractures in anterior and posterior primary teeth in children treated at the Center of Studies and Treatment of Traumatic Dental Injuries in Primary Dentition (NETRAD) (5).
Of the 643 total children who were treated at this center between 2002 and 2013, 26 children had at least one crown-root fracture according to the classification by Andreasen and Andreasen $(1,6)$. The information collected from clinical records included the age and sex of the child, details of the traumatized tooth, the etiology and place where the trauma occurred, the treatment adopted and the current situation of each case. The characteristics of all crown-root fractures were collected from clinical examinations, radiography and photographs.

Twenty-eight cases of crown-root fractures were found in 26 children, representing $4 \%$ of total injuries treated at the referral center during this period. The children's age at the trauma moment ranged from 19 to 65 months. There were $11(39.3 \%)$ cases in boys and $17(60.7 \%)$ in girls. The majority of injuries occurred at home (67.9\%), 25\% occurred on the street and $7.1 \%$ elsewhere. Falls were the main etiology $(50.0 \%)$, followed by falls from a height $(32.0 \%)$, collisions with inanimate objects $(10.7 \%)$, and traffic accidents (7.1\%).

In relation to the treatment performed, three options were considered: a) total extraction, where the entire tooth was removed in one session; b) partial extraction, where root fragments were left inside the alveolus; and c) pulpectomy, where the remaining tooth was retained and a subsequent restoration attempt was made. All cases were followed-up until the permanent successor tooth erupted.

Most of the teeth involved were the maxillary central incisors (85.7\%), followed by the maxillary lateral incisors $(10 \%)$, and molars $(3.6 \%)$. The lines of fracture in the crown and roots were observed to assess their extent and characteristics. Regarding the fracture lines in the crown, 
$57.1 \%$ of the cases had a simple line of fracture, and $42.9 \%$ had multiple lines. Simple lines predominated in the root (89.3\%). Of the cases with simple fracture lines in the crown, total extraction was performed in $37.6 \%$, while partial extraction was performed in $31.2 \%$ and pulpectomy only was required in $31.2 \%$. In most teeth with multiple lines of fractures in the crown, total extraction was performed (91.7\%) (Table 1).

According to the type of treatment, of the six cases that received partial extraction with the permanence of a fragment of root on the alveolus, total fragment root resorption was observed with the successful later eruption of the permanent tooth (Fig. 1). Regarding the cases that underwent total extraction, the permanent tooth has erupted in nine cases (Fig. 2) and eight are still being monitored. Of the cases that underwent pulpectomy, two have already experienced permanent tooth eruption (Fig. 3), two are in the root resorption process. Only one case was lost to follow-up.

\section{Discussion}

The objectives of the management of traumatic dental injuries in primary teeth are the comfort the child and parents in the acute state, to avoid inducing dental fear and anxiety in young children who may be experiencing their first dental problem, and to minimize the risk of further damage to the permanent teeth (7). The low prevalence of crown-root fractures found in this study (4\%) is in accordance with findings reported previously in the literature $(8,9)$. This finding is explained by the presence of immature supporting structures and the resilience of the bone surrounding the teeth (1), which usually results in a dental displacement instead of hard tissue trauma. However, crown-root fractures can cause complications, such as pain, difficulty in eating and speech, compromised aesthetics, and even psychological impact due to tooth loss (3), and therefore such injuries are recognized as important oral health problems (10). Most crown-root fractures occur in the anterior teeth, after direct trauma to the tooth itself (1). In this cases series, the majority of injured teeth were indeed incisors (95.7\%), and only one case affected a molar. Crown-root fractures in the primary molars are the most rare type of such injuries, and these generally result as a consequence of indirect trauma $(11,12)$.

Different patterns of fracture lines have been observed

Table 1. Presentation of 28 cases of crown-root fractures attended at NETRAD among the years 1992 to 2013. Pelotas, Brazil, 2014

\begin{tabular}{|c|c|c|c|c|c|c|c|}
\hline Cases & Sex & $\begin{array}{l}\text { Age of } \\
\text { trauma } \\
\text { (months) }\end{array}$ & Tooth & $\begin{array}{l}\text { Type of } \\
\text { crown } \\
\text { fracture }\end{array}$ & $\begin{array}{l}\text { Type } \\
\text { of root } \\
\text { fracture }\end{array}$ & Treatment & $\begin{array}{l}\text { Current } \\
\text { situation }\end{array}$ \\
\hline 1 & M & 60 & 61 & Multiple & Simple & Partial Extraction & $\mathrm{EP}$ \\
\hline 2 & M & 59 & 61 & Simple & Simple & pulpectomy & $\mathrm{R}$ \\
\hline 3 & M & 24 & 61 & Simple & Simple & Partial extraction & EP \\
\hline 4 & $\mathrm{~F}$ & 48 & 51 & Multiple & Simple & total extraction & EP \\
\hline 5 & M & 58 & 61 & Simple & Simple & partial extraction & EP \\
\hline 6 & M & 58 & 62 & Simple & Simple & total extraction & EP \\
\hline 7 & M & 54 & 51 & Multiple & Simple & total extraction & WE \\
\hline 8 & $\mathrm{~F}$ & 36 & 64 & Simple & Simple & total extraction & WE \\
\hline 9 & M & 30 & 61 & Multiple & Simple & total extraction & WE \\
\hline 10 & M & 19 & 51 & Multiple & Simple & total extraction & EP \\
\hline 11 & M & 36 & 61 & Simple & Simple & partial extraction & EP \\
\hline 12 & $\mathrm{~F}$ & 29 & 51 & Simple & Simple & pulpectomy & EP \\
\hline 13 & $\mathrm{~F}$ & 40 & 51 & Simple & Simple & total extraction & EP \\
\hline 14 & $\mathrm{~F}$ & 52 & 51 & Simple & Simple & pulpectomy & NN \\
\hline 15 & M & 33 & 61 & Simple & Simple & pulpectomy & $\mathrm{R}$ \\
\hline 16 & $\mathrm{~F}$ & 36 & 51 & Multiple & Simple & total extraction & $\mathrm{EP}$ \\
\hline 17 & $\mathrm{~F}$ & 21 & 61 & Multiple & Simple & total extraction & WE \\
\hline 18 & $\mathrm{~F}$ & 21 & 61 & Multiple & Simple & total extraction & WE \\
\hline 19 & M & 24 & 61 & Simple & Multiple & partial extraction & $\mathrm{EP}$ \\
\hline 20 & M & 30 & 61 & Simple & Multiple & total extraction & EP \\
\hline 21 & M & 36 & 51 & Multiple & Simple & total extraction & WE \\
\hline 22 & $\mathrm{~F}$ & 40 & 51 & Multiple & Simple & total extraction & WE \\
\hline 23 & $\mathrm{~F}$ & 30 & 62 & Simple & Simple & pulpectomy & $\mathrm{EP}$ \\
\hline 24 & $\mathrm{~F}$ & 30 & 61 & Multiple & Simple & total extraction & WE \\
\hline 25 & M & 22 & 61 & Multiple & Simple & total extraction & WE \\
\hline 26 & M & 25 & 62 & Simple & Multiple & Partial extraction & WE \\
\hline 27 & M & 31 & 51 & Simple & Simple & Total extraction & EP \\
\hline 28 & M & 65 & 51 & Simple & Simple & total extraction & $\mathrm{EP}$ \\
\hline
\end{tabular}

EP: erupted successor permanent tooth. WE: waiting the eruption of the successor permanent tooth. R: primary tooth root resorption. NN: not known. F: female M: male. *All teeth that received pulpectomy were restored with composite resin. 

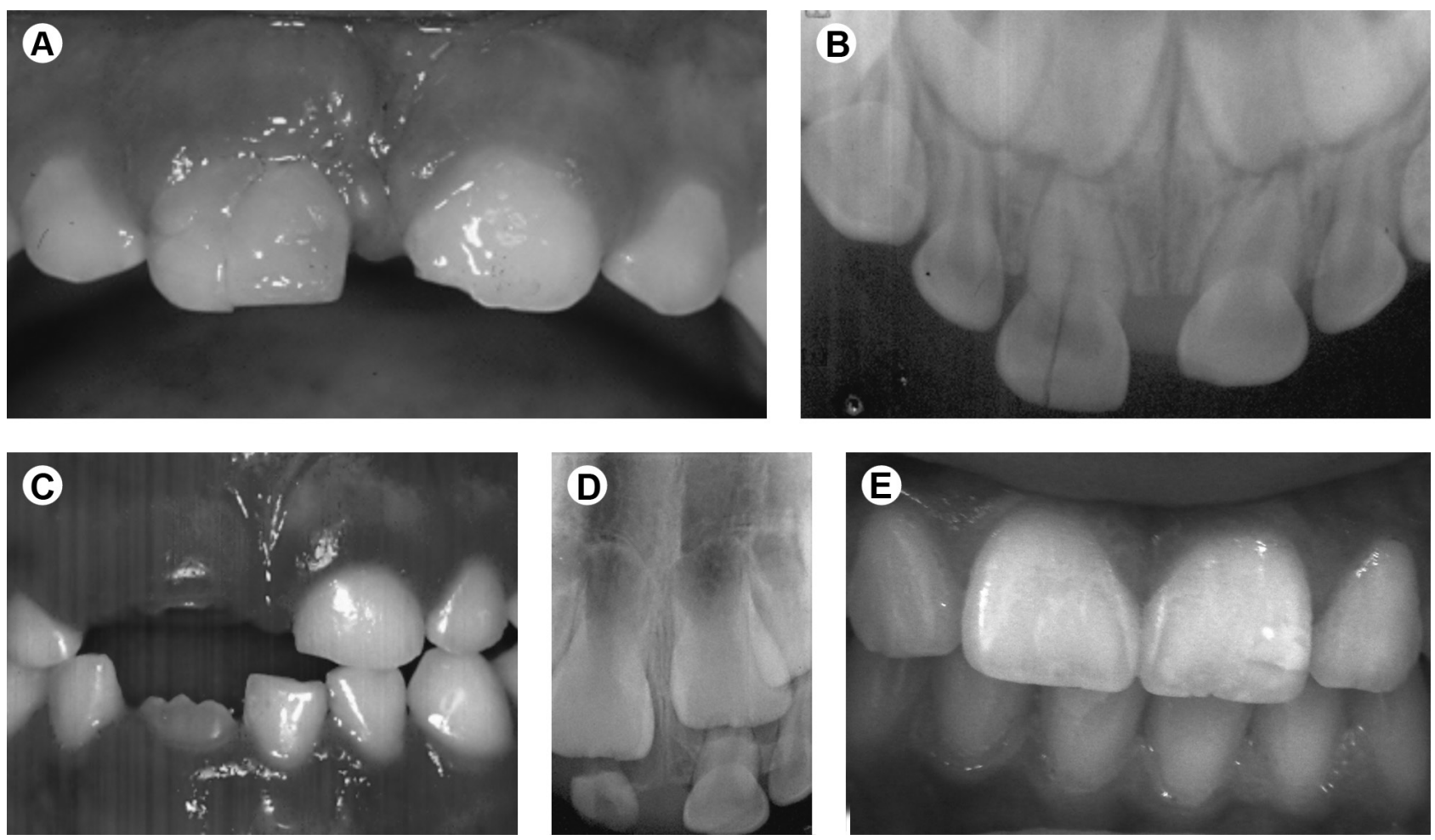

Figure 1. Crown-root fracture in maxillary right central primary incisor. Multiple fracture lines in the crown (A) and simple fracture line in the

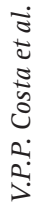
root (B). C,D: Follow-up of the residual root after the partial extraction. E: The boy, 5 years later, with a permanent successor tooth.
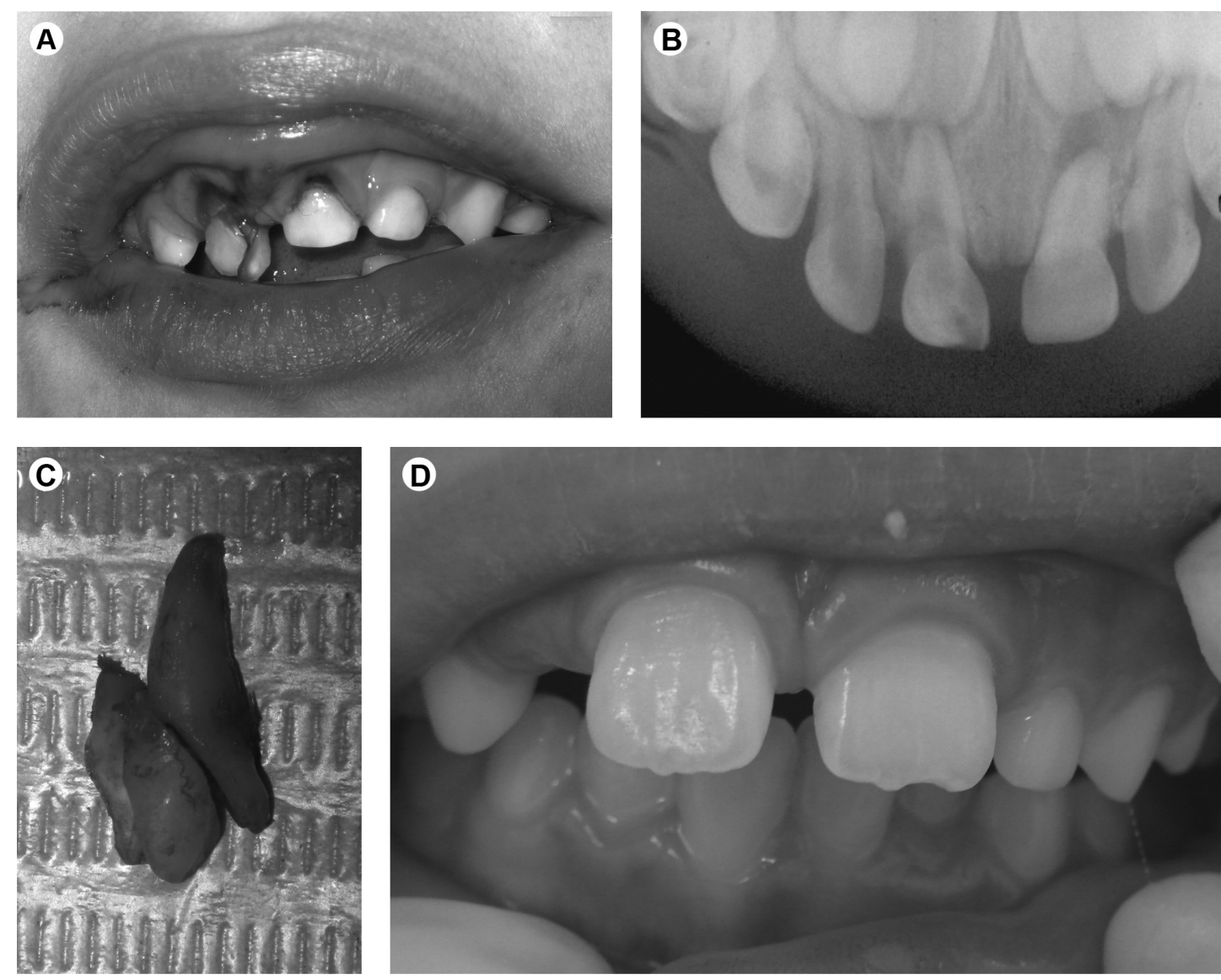

Figure 2. Crown-root fracture in maxillary left central primary incisor. Multiple fracture lines in the crown (A) and simple fracture line in the root (B). C: Full extraction of the tooth. C: The girl, 4 years later, with a permanent successor tooth. 
for both simple and multiple lines of fracture in the crown. Simple lines of fracture predominate in the root. This can be explained because when the tension zone is concentrated at the crown, the root does not suffer the greatest impact (1). This different pattern is difficult to diagnose and treat, due to limitations in the two-dimensional images achieved by radiographic examinations.

The treatment of traumatized teeth should respect the dental and periodontal structures involved. The dentist should be able to indicate effective therapeutic measures that provide the best possible prognosis. However, factors such as the severity of trauma, stage of root formation, time elapsed since the trauma, and adverse issues regarding the application of the techniques, will influence the treatment success (4).

The recommendations of the International Association of Dental Traumatology Guidelines for the treatment of crown-root fractures in primary teeth are the extraction of the fractured tooth. Care should be taken to prevent trauma to the permanent succedaneous tooth. Fragment removal should only be attempted if the fracture involves a small part of the root and the stable fragment is sufficiently large to allow coronal restoration (13). In this case series, we observed that multiple lines of fractures in the crown predominated and the most common treatment was total extraction as a result of the intraosseus extension that occurred in many of the fractures, which made tooth restoration attempts impossible.

Experimental and epidemiological studies have demonstrated the significant possibility of a more conservative approach to the treatment of primary trauma. Total extractions were not performed in this cases series in two situations: 1- when the possibility of pulp treatment and tooth restoration was recognized after the removal of the mobile fragment, which occurred primarily with diagonal fractures after the removal of the coronal fragment followed by a supragingival restoration to allow gingival healing (14); and 2- a partial extraction was conducted when the radicular fragment was very apical, in order to prevent permanent tooth bud damage during the removal of the apical root portion. Professional expertise, a well-conducted treatment, and most importantly a longterm follow-up are fundamental for the future health of traumatized primary teeth (15).

The dentist can have difficulty making a correct diagnosis and establishing an effective treatment plan for injuries that do not occur daily (4). In many situations, the total extraction of a tooth is not acceptable to the family and the preservation of the tooth structure gives an emotionally and socially positive response. Restoring a primary tooth is a challenge. The bonding to the enamel could be effectively achieved determining the concentration of the acid etchant and the etching team, although the acid etching performed a selective demineralization because of morphological disposition of the enamel rods and primary aprismatic enamel. On the other hand, the bonding to dentin is more difficult due to its heterogeneous nature and presence of water, presence of smear layer and smear plugs (16). However, studies demonstrate a satisfactory survival for restorations performed in primary teeth after 48 months of follow-up (17).

In this cases series, it was observed that the management
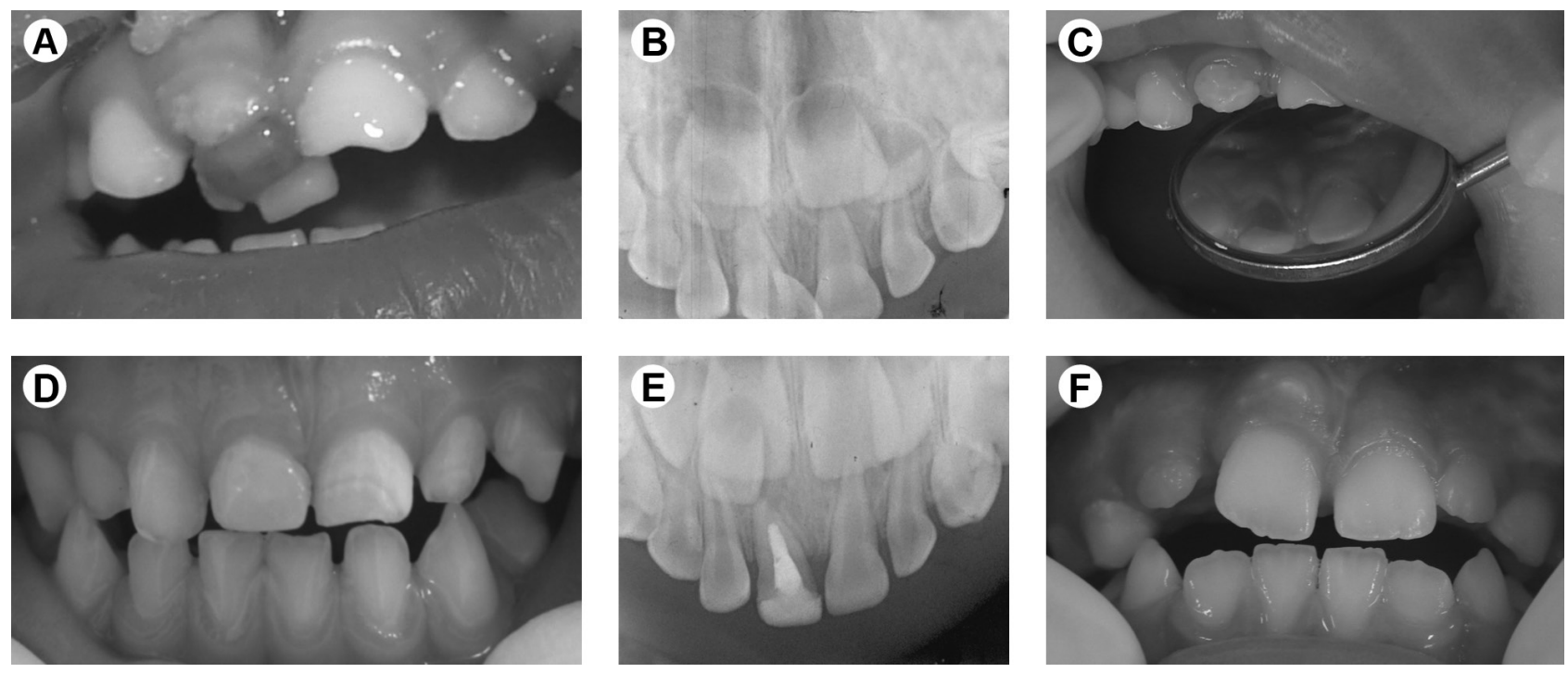

Figure 3. Crown-root fracture in maxillary left central primary incisor. Multiple fracture lines in the crown (A) and simple fracture line in the root (B). C: Removal of the small fractured tooth portion. D, E: Pulpectomy and restoration. F: The girl, 4 years later, after eruption of the permanent successor tooth. 
of all teeth was successful regardless of the treatment received, as the eruption of the permanent successor occurred without sequelae. With that emphasis, the importance of regular monitoring for possible complications should be instituted.

Few reports of this type of fracture with longitudinal follow-up are found in the literature. The crown-root fractures in primary teeth present very distinct clinical and radiographic characteristics, influencing the treatment performed. Regardless of the procedure adopted, all of the cases showed favorable prognoses.

\section{Resumo}

Fraturas coronorradiculares em dentes decíduos são raras, com uma ampla variação de padrões que dificultam o diagnóstico e tratamento. 0 objetivo deste estudo foi apresentar uma série de casos de fraturas coronorradiculares na dentição decídua de crianças atendidas em um centro de referência. 0 estudo acompanhou 28 casos de fratura coronorradicular em 26 crianças, representando 4\% do número total de participantes ao longo de 11 anos no serviço de referência na Universidade Federal de Pelotas. Na maioria dos casos, o incisivo central superior $(85,7 \%)$ foi o mais envolvido. Na coroa, $57,1 \%$ dos casos tiveram linha de fratura simples, e 42,9\% tiveram múltiplas linhas. As linhas simples predominaram na raiz $(89,3 \%)$. Nos casos com linhas de fratura simples na coroa, 37,6\% foram submetidos à extração total, 31,2\% necessitaram de extração parcial e $31,2 \%$ de pulpectomia. A maioria dos dentes com ¿ múltiplas linhas de fratura na coroa, a extração total foi realizada $(91,7 \%)$.

¿ Todos os casos foram acompanhados até a erupção do dente permanente sucessor, e todos os pacientes tiveram resultados favoráveis.

\section{Acknowledgements}

The authors would like to thank the Professor Dione Dias Torriani (in memorian) for her commitment and dedication to NETRAD. This service was designed by her, derived from her study about the traumatic dental injuries throughout her career.

\section{References}

1. Andreasen J0, Andreasen FM. Textbook and Color Atlas of Traumatic Injuries to the Teeth. Oxford. Wiley-Blackwell, 2007:912p.

2. Borum MK, Andreasen J0. Therapeutic and economic implications of traumatic dental injuries in Denmark: an estimate based on 7549 patients treated at a major trauma centre. Int J Paediatr Dent 2001;11:249-258.
3. Flores MT, Malmgren B, Andersson L, Andreasen JO, Bakland LK, Barnett

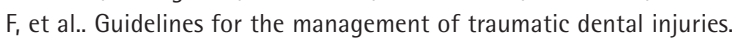
III. Primary teeth. Dent Traumatol 2007;23:196-202.

4. de Castro MA, Poi WR, de Castro JC, Panzarini SR, Sonoda CK, Trevisan $\mathrm{CL}_{\text {, et }}$ al.. Crown and crown-root fractures: an evaluation of the treatment plans for management proposed by 154 specialists in restorative dentistry. Dent Traumatol 2010;26:236-242.

5. Costa VP, Bertoldi AD, Baldissera EZ, Goettems ML, Correa MB, Torriani DD. Traumatic dental injuries in primary teeth: severity and related factors observed at a specialist treatment centre in Brazil. Eur Arch Paediatr Dent 2014;15:83-88.

6. Abanto J, Carvalho TS, Mendes FM, Wanderley MT, Bönecker M, Raggio DP. Impact of oral diseases and disorders on oral health-related quality of life of preschool children. Community Dent Oral Epidemiol 2011,39:105-114.

7. Liu $X$, Huang J, Bai $Y$, Wang $X$, Baker $A$, Chen $F$, et al.. Conservation of root-fractured primary teeth--report of a case. Dent Traumatol 2013;29:498-501.

8. Götze $G$ da $R$, Barreira AK, Maia LC. Crown-root fracture of a lower first primary molar: report of an unusual case. Dent Traumatol 2008;24:377-380.

9. Lima MD, Moura MS, Leopoldino VD, Batista-Netto OS, Carvalho CM, Moura LF. Crown-root fracture of fused primary teeth - a case report. Gen Dent 2012;60:101-103.

10. Jesus MA, Antunes LA, Risso PA, Freire MV, Maia LC. Epidemiologic survey of traumatic dental injuries in children seen at the Federal University of Rio de Janeiro, Brazil. Braz Oral Res 2010;24:89-94.

11. Sasaki H, Ogawa T, Kawaguchi M, Sobue $S$, Ooshima T. Multiple fractures of primary molars caused by injuries to the chin: report of two cases. Endod Dent Traumatol 2000;16:43-46.

12. Tejani Z, Johnson A, Mason C, Goodman J. Multiple crown-root fractures in primary molars and a suspected subcondylar fracture following trauma: a report of a case. Dent Traumatol 2008;24:253-256.

13. Malmgren B, Andreasen JO, Flores MT, Robertson A, Di Angelis AJ, Andersson $L$, et al.. International Association of Dental Traumatology guidelines for the management of traumatic dental injuries: 3 . Injuries in the primary dentition. Dent Traumatol 2012;28:174-182.

14. Turkistani J, Hanno A. Recent trends in the management of dentoalveolar traumatic injuries to primary and young permanent teeth. Dent Traumatol 2011;27:46-54.

15. Cunha RF, Pugliesi DM, Percinoto C. Treatment of traumatized primary teeth: a conservative approach. Dent Traumatol 2007;23:360-363.

16. Mithiborwala $\mathrm{SH}$, Chaugule V, Katge F, Poojari M, Pujari P, Pammi T. A comparative evaluation of the efficacy of etching by the total etch and self-etch dentin bonding systems in the primary teeth: An in vitro study. Int J Clin Pediatr Dent 2015;8:30-36.

17. Pinto GS, Oliveira $\sqcup$, Romano $A R$, Schardosim LR, Bonow ML, Pacce $M$, et al.. Longevity of posterior restorations in primary teeth: results from a paediatric dental clinic. J Dent 2014;42:1248-1254.

Received June 1, 2015 Accepted February 23, 2016 